\title{
MODELS OF FOREIGN LANGUAGE PRIMARY SCHOOL TEACHER TRAINING IN THE EU
}

\section{Olga Kotenko ${ }^{1}$ \\ Tetiana Holovatenko ${ }^{2}$}

DOI: https://doi.org/10.30525/978-9934-588-38-9-5

\begin{abstract}
The paper discusses various models of initial training of foreign language teachers to working in primary schools. We are guided by two research questions in the study: what models of FL primary school training are common around Europe and what models are already implemented in Ukraine. We assume that all countries in the Bologna process will have similar challenges and models of implementation of teacher training. Thus, this study is based on comparative education constructivist methodology. We study European legislative provision of teacher training, Eurydice reports and curriculums of teacher training in higher education establishments on levels 6 and 7 of International Standard Classification of Education (ISCED). As a result, we presents a comprehensive model of higher education for future primary school foreign language teachers. The model comprises structural, functional models, and models of foreign language graduate teachers.
\end{abstract}

The structural models represent the whole system of higher education and comprise binary, unitary and differential sub-models. In this paper a binary model we present through an example of teacher training in Belgium. The unitary model is analysed on the example of Finnish higher education legislative provision, and the differential model is represented by French experience in the field.

Functional models represent the correlation between theoretical and practical teacher training. In this paper we analyse two sub-models: concurrent and consecutive. We study the features of organizing concurrent teacher training according to these models on the example of Luxembourg

${ }^{1}$ Candidate of Pedagogical Sciences,

Associate Professor at Department of Foreign Languages and Methodologies,

Borys Grinchenko Kyiv University, Ukraine

${ }^{2}$ Lecturer at Department of Foreign Languages and Methodologies,

Borys Grinchenko Kyiv University, Ukraine 
and the Czech Republic. The consecutive model of teacher training is presented through examples of Germany and France.

This study outlines three models of graduates, who are allowed to teach foreign languages in primary schools: generalist, semi-specialist and specialist teachers. We study two cases (Luxembourgish and Italian) of generalist teacher training in multilingual regions. They are compared with semi-specialist teacher training models on examples of Denmark and Finland. Specialist teacher training model, as opposed to previous ones allows teachers to study the language more deeply and to be enrolled into a course (Ukraine) or study the methodology of teaching as a separate subject (Portugal).

Based on the results of the research and the model presented, we made an attempt to classify Ukrainian experience of FL primary school teacher training. From the outcome of our investigation it is possible to conclude that Ukrainian higher education system is represented by a binary model. Taking into account a curriculum of teacher training (specialties "Primary Education" and "Language and Literature (English)", we can conclude it is organized according to a concurrent model of generalist and specialist teacher training.

Further research is needed on tendencies of teacher training to teaching foreign languages to young learners.

\section{Introduction}

Ukrainian higher education undergoes a series of reforms during the last decade. Most of them are rooted in the process of integration of the system of higher education into the European Higher Education Area. The process started in 2005 with implementation of Bologna declaration and reforming the structure of higher education. The next step was shaping a general vision of reforms in Ukrainian education (National Strategy of Education Development in Ukraine in 2012-2021, Law "On Higher Education" (2014), Law "On Education" (2017), and Strategy of Reforming Higher Education in Ukraine till 2020"). These documents aim at finding "...various educational models" [35], implementing innovations into education and creating the system of quality assurance, as well as increasing the level of integration into the European Higher Education Area. The need for enhancing European cooperation was deepened 
by the "Association Agreement between the European Union and its Member States, of the one part, and Ukraine, of the other part". Through Articles 431 of the chapter "Education, training and youth" the following priorities are set: “...reforming and modernising the higher education system, promoting convergence in the field of higher education deriving from the Bologna process; enhancing the quality and relevance of higher education; stepping up cooperation between higher education institutions; building up the capacity of higher education institutions". With European integration of Ukraine, the issue of language proficiency arises. As preschool and primary school students only start learning languages, it is important for teachers of this stage to be highly qualified. So in this paper we aim at studying various models of organizing teacher education across Europe and identify models of FL primary school teacher training implied in Ukraine.

The literature on European experience on models of teacher training shows a variety of approaches and views. The research group of the unit "Schools and Multilingualism" of the European Commission dwells on the notion of initial teacher education. Researchers indicate, that this stage is especially important, as all professional competences of future teachers are set [9, p. 14]. Researchers assume that initial teacher training in complex with practical training and continuous professional development can become a response to "...changing needs of the educational process" [9, p. 15]. However, depending on the correlation between the first two components, there are different initial teacher training models in educational institutions across Europe. At the same time the system of institutions, where initial primary school teacher training is provided also differs greatly across European Higher Education Area.

Reforms in initial teacher training concern three major blocks: institutions providing teacher education, the content of teacher training and the correlation between teaching practice and teacher education. One of the cases, similar to Ukrainian, is provided by Turkish system of initial primary school teacher training. Turkey has become a member of Bologna Process since 2001 and has undertaken the same structural reforms of initial preprimary and primary education as Ukraine did (organising Bachelor's and Master's studies, implementing concurrent system of primary school teacher training). At the same time, reforming the Turkish model of teacher training 
was carried out simultaneously with structural reforms. Nevertheless, the following issues in teacher training have risen: the quality of education, high workload of staff, equipment of classrooms, instructional materials and student social services etc [16, pp. 365-367]. Scholars see that as a result of reforms carried out. We can notice that Ukrainian system of primary school teacher training has also faced the same problems to some extent. Thus, we can say that learning foreign experience can help us predict the way the model of teacher training is going to work.

Preliminary attempt to study the influence of both functional models on enrollee's was made in Irish context. The research measure if functional models influence enrollee's attitudes towards Mathematics within traditional and alternative initial teacher education routes. Researchers have analysed peculiarities of concurrent and consecutive teacher training models and after the study concluded that both models do not differ in terms of results and extend of influence on attitudes towards Mathematics [14, pp. 13-15].

Another attempt to compare functional models of teacher training was made by R. Zuzovsky and S. Donitsa-Schmidt. The comparison was made in terms of efficiency and equity. After the 10-year study researchers proved that students, who studied according to the consecutive model demonstrated better performance. However, scholars notice that due to a number of limitations in the study, we cannot assume concurrent model is ineffective [33, pp. 6, 15-16].

Previous studies indicate that scholars mainly focused on the initial teacher training model performance, rather than considering outcomes and possibilities of such training for those, who can work as foreign language (FL) teachers in primary schools. However, the latest research on pre-service teacher training to working in multilingual primary schools bridges this gap. Scholars analyse curriculums of primary school teacher training in 5 European countries in pre-border regions. Among the findings of the research are several cases: introduction of the bilingual curriculum with 2 languages of instruction; equal usage of 3 languages in the curriculum (regional, minority and state language); dominant usage of state language and inclusion of regional and FL $[26$, p. 11]. We are going to analyze these models of preparing preservice primary school FL teachers. 


\section{Methodology of research}

In this research we were guided by the following research questions:

- what are various models of FL primary school teacher training around EU countries and how their components are interrelated.

- what models of FL primary school teacher training are implied in Ukraine.

This study is built upon the research of models of teacher training suggested by S. Vitvytska, Z. Sederevičiūtè-Pačiauskienè, B. Vainorytė, N. Raud and O. Orehova. However, our focus is specifically on models of primary school FL teacher training.

Thus, based on the aim, a descriptive comparative research methodology is applied to research the topic. The literature review comprises analysis of European legislation on teacher training, legislative provision of teacher training in specific countries, curriculums of primary school teacher training in various higher education institutions, Eurydice network reports and information on national systems of education and the system of initial teacher training for early childhood and primary schools, electronic Scopus database, Ukrainian and foreign academic literature to set the discourse and compare scholars' views.

Initial teacher training takes place at ISCED 6 and 7 levels, which corresponds to Bachelor's and Master's levels of education [29]. However, there are various higher education institutions providing teacher training at this level. Our aim is to analyse such models of primary school FL teacher training. According to constructivist methodology, modeling is one of basic comparative research methods. We take a look at various European models through a case study method.

Thus, in Section 3 we dwell on the notion of "model" in Comparative Education research. The classification of European models of higher education for future primary school FL teachers are presented in Section 4-6. Section 7 analyses Ukrainian experience on the issue and summary of the results of this paper and conclusions are provided in Section 8.

\section{Modeling as a method of comparative research}

A special emphasis on the importance of modeling in the context of reforming pedagogical education was put by the Concept of Pedagogical Education $[38$, p. 5]. One of the tasks of reforming pedagogical education is 
"...developing a modern model of reforming of pedagogical profession..." $[38$, p. 5]. One of the components of reforms in pedagogical education is changing the model of teacher training and aligning it with the vision of a teacher within the reform.

According to Oxford Advanced Dictionary, model is “...a simple description of a system, used for explaining how something works or calculating what might happen, etc." [25]. One of varieties of models is an educational model. According to the Encyclopedia of Information Science and Technology, educational model is considered to be an "abstract from real human behavior in teaching and training... can represent theories of learning, pedagogic, and didactic" [23]. So, we see a model as an intermediate between theory and its practice. However, based on the constructivist methodology, we consider modeling of professional training to be a means of generalizing of professional training experience and predicting the following development of the system within some setting.

Eurydice has acknowledged 2 models of initial teacher training: consecutive and concurrent models [8]. However, this classification concerns only the organization of the content of initial training. This view lacks views on various paths future teachers can take to become in-service teachers. At the same time, considering the aim of our research, this model does not reflect peculiarities of primary school teacher training to teaching FL.

A major attempt to classify models of teacher education was made by S. Vitvytska. The scholar splits educational models into 3 types: descriptive, functional and prognostic [34, p. 17].

According to the scholar, descriptive models aim at describing the system of education. They are split into binary, unitary and differential model. However, besides the notion of the structure of the education, we should take into account the legislative provision, that supports this structure. Thus, we suggest this group of models to be called structural and comprise legislation for the level of education it supports. Functional group of models is considered to describe the interrelations between the components of the teacher training curriculum. Within this group the scholar distinguishes concurrent, integrated and consecutive models of teacher training [34, p. 17]. However, very few publications were found in the literature addressing the issue of integrated models. So, to avoid confusion in this paper we are going to follow the generally acknowledged 
view on splitting this group of teacher training models on consecutive and concurrent. Prognostic models of teacher training, according to the author, aim at predicting tendencies of teacher training. However, our paper does not include it as our task, so we are not going to dwell on it.

Table 1

Models of higher education for in-service primary school FL teachers

\begin{tabular}{|c|c|c|c|}
\hline \multicolumn{4}{|c|}{ Structural models } \\
\hline Binary model & \multicolumn{2}{|c|}{ Unitary model } & Differential model \\
\hline $\begin{array}{l}\text { Comprises university } \\
\text { and non-university sector } \\
\text { providing ac-ademic and } \\
\text { professional orient-ed } \\
\text { training respectively. }\end{array}$ & \multicolumn{2}{|c|}{$\begin{array}{l}\text { Comprises universities and } \\
\text { col-leges in its structure, } \\
\text { providing both academic } \\
\text { and professional oriented } \\
\text { training. }\end{array}$} & $\begin{array}{l}\text { Comprises several types } \\
\text { of higher education } \\
\text { institutions: long cycle } \\
\text { programs at univer-sities } \\
\text { or similar institutions and } \\
\text { short cycle programs at } \\
\text { insti-tutes or sections of } \\
\text { teacher training. }\end{array}$ \\
\hline $\begin{array}{l}\text { Examples: Germany, } \\
\text { Norway, Belgium, } \\
\text { Denmark, the Nether-lands }\end{array}$ & \multicolumn{2}{|c|}{$\begin{array}{l}\text { Examples: Sweden, Italy, } \\
\text { Aus-tria, Finland, USA, } \\
\text { Great Brit-ain }\end{array}$} & $\begin{array}{l}\text { Examples: France, } \\
\text { Denmark }\end{array}$ \\
\hline \multicolumn{4}{|c|}{ Functional models } \\
\hline \multicolumn{2}{|c|}{ Concurrent model } & \multicolumn{2}{|c|}{ Consecutive model } \\
\hline \multicolumn{2}{|c|}{$\begin{array}{l}\text { Future teachers study psychological, } \\
\text { general pedagogical and specific subject } \\
\text { courses and at undergoing pedagogical } \\
\text { training at the same time. }\end{array}$} & \multicolumn{2}{|c|}{$\begin{array}{l}\text { Future teachers are getting their practical } \\
\text { training after finishing general education }\end{array}$} \\
\hline \multicolumn{2}{|l|}{$\begin{array}{l}\text { Examples: Czech Republic, } \\
\text { Luxembourg... } \\
\end{array}$} & \multicolumn{2}{|c|}{ Examples: Germany, France... } \\
\hline \multicolumn{4}{|c|}{ Models of FL graduate teachers } \\
\hline Generalist teacher & \multicolumn{2}{|c|}{ Semi-specialist teacher } & Specialist teacher \\
\hline $\begin{array}{l}\text { Qualified to teach all } \\
\text { subjects of the primary } \\
\text { school curricu-lum } \\
\text { (including FL). }\end{array}$ & \multicolumn{2}{|c|}{$\begin{array}{l}\text { Qualified to teach at least } \\
3 \text { subjects at primary } \\
\text { schools. }\end{array}$} & $\begin{array}{l}\text { Philologist, qualified to } \\
\text { teach one or two language } \\
\text { subjects at a primary } \\
\text { school. }\end{array}$ \\
\hline $\begin{array}{l}\text { Examples: Belgium } \\
\text { (Flanders), France, } \\
\text { Italy, the Netherlands, } \\
\text { Luxembourg... }\end{array}$ & \multicolumn{2}{|c|}{ Examples: Denmark ${ }^{1}$} & $\begin{array}{l}\text { Examples: Greece, } \\
\text { Spain, Cro-atia, Portugal, } \\
\text { Slovakia... }\end{array}$ \\
\hline
\end{tabular}

${ }^{1}$ In other countries there are more flexible regulations regarding FL teachers in primary schools (e.g. generalist+semi-specialist or semi-specialist+specialist) 
At the same time, as we are discussing the issue of primary school teacher training to teaching FL, we should take into account different models of graduates, who are going to teach FL in primary schools. According to Eurydice, there are 3 models of language teachers in primary school. They are generalist teacher, semi-specialist teacher and specialist teacher [4, p. 85]. The structure and relation between all these models can be represented in the following table 1.

\section{Structural models of education}

Structural models of education comprise three different groups of models (binary, unitary and differential) of higher education, aiming at outlining a general hierarchy of levels of education (based on specific legislative provision) and specific type of institutions providing education at this level.

Binary model of education comprises 2 educational sectors: university and non-university sector. Universities aim at academic-centered training and research. Non-university sector aims at professional training.

One of the features of the binary education system is its strict orientation on either practice or research from the very beginning of their studies. It can be an advantage if an enrollee has already chosen the career to pursue in future. However, one of the disadvantages of the system is a complicated transfer between university and non-university sector [34, p. 17].

Examples of countries with binary model of education are Germany, Norway, Belgium, Denmark, the Netherlands etc.

For instance, the Kingdom of Belgium has 3 linguistic regions: Dutchspeaking Flanders, French-speaking Wallonia and a German-speaking community. Higher pedagogical education obtained at ISCED 6 level allows students to teach at primary schools. According to ISCED 6, Bachelor's or equivalent level can be obtained in 3 or 4 years [29, p. 53].

According to Flemish Law "On Higher Education" (Chapter 1, Article I.2) higher education is provided in universities and colleges (hogeschool). According to Article II.64, to obtain the Bachelor's degree in Flanders, students need to accumulate 180 ECTS credits either at professionally or academically oriented higher education institutions. Thus, the binary model of higher education is legislatively set by the Law "On Higher Education".

Legislative provision for the binary higher education in French-speaking Wallonia is set by the "Décret définissant le paysage de l'enseignement supérieur 
et l'organisation académique des etudes" (2013). According to the Decret (Article 1 and 4), higher education at ISCED 6 level is provided at universities, hautes écoles and schools of art [6]. Primary school teachers are prepared at hautes écoles. They can also teach FL, if the combination of their subject allows it.

Although Belgian higher education is built according to a binary model, the example of the German-speaking community differs. As the community is small, there is only one institution providing pedagogical education Autonomous Higher School in German-speaking Community. Students can get Bachelor's degree in 3 years, get practical training at referendariat and either start working at primary schools or enroll to university studies in French-speaking Wallonia [7].

So, we can conclude that in Belgium professionally-oriented primary school teacher training takes place only at colleges (hogeschools), but there is also a possibility to pursue academic career through university studies. This structure forms binary model of teacher education.

Unitary model of education consists of universities and colleges in its structure. Universities and colleges offer academic and professional oriented cycles with different duration of various programs. However, in contrast to the binary model of higher education, they all belong to an integrated university center.

One of the advantages of the unitary model is a rather simplified system of transfer between the levels of education within one university.

Examples of unitary higher education model are in Sweden, Italy, Austria, Finland [34, p. 15].

For instance, Finnish higher education is represented by universities and universities of applied sciences [10]. Primary school teachers are prepared at universities. The legislative provision for university education is the "Universities Act" [31].

Differential model of education comprises several types of higher education institutions. For instance, long cycle programs provided by universities or similar institutions and short cycle programs at institutes or sections of teacher training.

One of the advantages of this model is a wide variety of institutions to build personal professional growth. However, as we can conclude from such a complex system, transferring between these institutions differs and needs centralized management of the system of higher education. 
A typical example of the differential model of higher education is the French one. The peculiarities of French system of higher education are its complexity. According to the French Education Code, there are 4 types of higher education institutions: universities, schools and institutes outside of universities, higher education institutions, French schools abroad and «grands établissements» (major institutions), and Communities of Universities and Schools [19].

Since 2013, primary school teachers are prepared at universities to get Bachelor's degree. On obtaining Bachelor's degree, future teachers pass the test and choose the type of school they would like to teach at. Further education takes place in schools, which are parts of universities and are called Ecoles Supérieures du Professorat et de l'Education (ESPE). They provide professional Master's degree for primary school teachers, which allows them to be enrolled into the national appointment system in their académie (educational region) [5, p. 290, 300].

Based on the results of analysis of structural models of higher education we can conclude that higher education for primary school teacher is provided at ISCED 6 level across Europe. However, types of educational institutions providing it, varies greatly. At the same time, various models exist on the level of content of teacher training.

\section{Functional models of teacher training}

Functional models of teacher training refer to the correlation of theoretical training and practice of future teachers within the curriculum. Traditionally, Eurydice distinguishes concurrent and consecutive models of teacher training.

Concurrent model of teacher training is based on integrity of theoretical and practical teacher training. Future teachers study psychological, general pedagogical and specific subject courses at the same time with undergoing pedagogical training [8].

Among the advantages of the concurrent model, Ž. SederevičiūtèPačiauskienė and B. Vainorytė mention: integration of both theoretical and practical knowledge, developing and "shaping" of students' pedagogical interests, as well as doing research on problems concerning education [27, p. 348].

One of the arguments Ž. Sederevičiūtè-Pačiauskienè and B. Vainorytė give in favour of concurrent model is a significant amount of pedagogical 
practice, which helps professional identification of future teachers and develops their professional competence [27, p. 349].

Let us have a look at examples of organizing concurrent primary school teacher training at the University of Luxembourg and Masaryk University (Czech Republic).

The University of Luxembourg provides future primary school teachers with 240 ECTS program, divided between 8 semesters [21]. After graduating the program, teachers can work in primary schools, preparatory and extracurricular institutions or continue studies at Master's degree [2, p. 5].

Educational process at the University of Luxembourg is divided into 2 cycles. The first 4 semesters are theoretical, because students study basic psychological and pedagogical subjects. During the second year of studies a semester of mobility is compulsory for all students. Students study in a country foreign country and practice their language skills [1].

Practical training of teachers starts from the first semester of their studies and takes place in various educational institutions (schools, extracurricular institutions etc.) [2, p. 7]. However, one of the major peculiarities in primary school teacher training at the University of Luxembourg is the organization of subject pedagogical workshops (Lehrund Lernwerkstätte) as medium between theory and practice. There are Language, Maths, Science, Art and Aesthetics, Education in Movement, Games and Sport workshops. During the third and fourth year of studies students work on preparing project for primary schools at workshops and their further implementation during practical training in schools, youth centres and other education institutions [3].

Pedagogical internship takes 64 ECTS credits (26.6\%) within the 240 ECTS credit curriculum. However, working on projects in workshops helps students to increase the level of preparedness before real-life teaching [2, p. 7].

So, concurrent primary school teacher training in Luxembourg has its peculiarities. Firstly, future teachers have practical training from the first semester of Bachelor's studies. Secondly, to increase the level of students' professionalization, workshops as a medium between theory and practice exist. Lastly, throughout the curriculum practical training occupies $26.6 \%$ of instruction time. 
However, primary school teacher training across Europe has its variations. For instance, in the Czech Republic (Masaryk University) primary school teachers are admitted to programs leading straight to Master's degree. In the 5-year curriculum all subject fall into the following categories: a subject module (the basics of all educational areas taught at the first stage of the basic school); a pedagogical and psychological module (including practical training); a university basics module (philosophy, history, rhetoric, ecology, computer technology etc.); a didactic module (theory and practice of teaching individual educational areas at the first stage of the basic school); an upgrading module; a specialisation module (the systematic study of the chosen specialisation - either one of the subjects focused only on educational care or language) [12]. The analysis of the curriculum of primary school teacher training at Masaryk University allows us to state pedagogical training comprises approximately $10 \%$ of the curriculum from the first to the last semester [24].

Comparing the implementation of concurrent teacher training model in Luxembourg and in the Czech Republic, we came up with the following conclusions: although practical training according to concurrent model of teacher training takes place every semester, its amount depends on the university and varies from program to program. In some universities, practically oriented workshops are introduced in the program to develop primary school teacher's skills before a real-life practice at schools.

In the consecutive model of teacher training, students are getting their practical training after finishing general education [8].

As Ž. Sederevičiūtè-Pačiauskienè and B. Vainorytė imply, this model is financially justified, as expenses to sustain the system of teacher training are relatively lower. One of other reasons is reduction of university teacher training time and, as a result, reducing the shortage of teachers [27, p. 349].

Implementation and functioning of consecutive teacher training model varies across Europe. Let us have a look at 2 examples of primary school teacher training: in Germany and France.

To become a primary school teacher in Germany you can enroll into one of the following specialties: "Lehramt an Grundschulen" ("Primary School Teacher"), "Lehramt für die Primarstufe mit oder ohne inklusionspädagogischer Schwerpunktbildung" ("Teacher of the First Level of Education with or without Inclusive Education», Brandenburg) and 
"Lehramt für die Primarstufe" ("Teacher of the First Level of Education", Nordrhein-Westfalen) [17, p. 5].

One of the peculiarities of German primary school teacher training is on one side a continuous teacher practice throughout the curriculum and on the other hand all teachers should undergo a stage of practical training called "referendariat" (Vorbereitungsdienst). Thus, we can conclude teacher training in Germany is organized according to the consecutive model. Due to the autonomy of Lands in Germany, educational affairs are the responsibility of each autonomous land. For instance, the Law "On Teacher's Education in Brandenbourg" (Brandenburgisches Lehrerbildungsgesetz) consists of 6 chapters and 18 paragraphs. According to the first chapter of the Law, universities have autonomy in designing the inner quality of pedagogical training provision [18]. However, the same Law states that the 2 stage system of university studies and referendariat should be unchanged. The second chapter of the Law outlines the general structure of teacher training at Bachelor's level: students study 2 subjects aiming at scientific or cultural education, specialization, methodology of teaching and intensive practice. At Bachelor's level future teachers get 180 ECTS credits. 120 ECTS credits they can get at Master's level. Moreover, practical training for 12 months at referendariat is compulsory [18].

So, in Germany primary school teacher training is consecutive in its nature, but nevertheless students have practical training during the Bachelor's and Master's studies.

In contrast to German experience of organizing consecutive model of teacher training, French experience provides us a different approach to organizing consecutive teacher training. According to the 2013 reform of the initial training, after pursuing Bachelor's degree all students get enrolled into Master's studies. To become primary school teachers, students study and get practical training at Ecoles Supérieures du Professorat et de l'Education (ESPE). As it is stated in Eurydice report, the first experience of teaching at primary schools and teaching FL to young learners in particular, students get only during ESPE practice. Students observe children and classes in primary schools during their first year of Master's studies. At the same time, they prepare Master's thesis research and get ready to pass a competitive exam on teaching profession. During their second year of Master's studies, future teachers become trainees and work halftime at primary schools [11]. 
Thus, French model of consecutive teacher training does not include teacher training during general studies of future primary school teachers. We can conclude this system is a little similar to German stage of practical teacher training. At the same time, there are a number of differences: German referendariat takes place after Master's studies, but French stage of practical training takes place during Master's studies. In Germany future primary school teachers work as full time teachers, however in France - as half-time teachers. The organisation responsible for organizing pedagogical training is a part of a university in France, but in Germany it belongs to state.

So, the organization of primary school teacher training is on one hand structured according to the European degree system (Bachelor's, Master's and $\mathrm{PhD}$ degrees), but at the same time has its national peculiarities.

\section{Graduate foreign language teacher model}

According to the aim of our research, we also need to mention a specific category of models, reflecting not only the content of teacher training, but also a model of a professional, who is admitted to teach primary school students FL. European Commission distinguishes 3 models of teachers, who can teach FL in primary schools: generalist, semi-specialist, and specialist teachers [4, pp. 142-144]. In various European countries regulations regarding the qualification of a graduate vary.

Generalist teachers can teach all subjects of the primary school curriculum (including FL). According to the Eurydice report data, in 11 educational systems around the European Union only generalist teachers are allowed to teach FL at primary schools [4, p. 85].

Let us have a look at Luxembourgish and Italian examples of generalist teacher training. In terms of languages the Grand Duchy of Luxembourg is a multilingual country. According to the Law "On Language Regime" Luxembourgish is a national language; French is the language of laws; Luxembourgish, French and German can be used in administrative and legal affairs [20, pp. 196-197]. Thus, it directly influences languages in education and the system of teacher training to working in the multilingual environment.

According to the curriculum of primary school teacher training at the University of Luxembourg we found out modules "Language Education" (26 ECTS credits) are compulsory and comprise $10.83 \%$ of the curriculum 
at the content level [2, p. 7]. It is also worth mentioning, all the subjects are taught either in German, French, Luxembourgish or English. Students, who struggle with any of these languages, can join the University of Luxembourg Language Centre. It offers MOODLE courses, language and conversation courses, online resources, tandem learning and consultations [32].

Luxembourgish model of generalist teacher training provides graduates with opportunities to develop their language skills not only through language courses, but also through studying non-language subjects in a non-dominant language.

Italy is also one of the countries where only generalist teachers are qualified to teach FL in primary schools. Multilingual teacher preparation takes various forms in Italy. One of the examples is provided by the Free University of Bozen-Bolzano. The university is situated in a pre-border region, where German, Italian and Ladin are spoken [26, pp. 5-7]. Future primary school teachers can enroll into a 300 ECTS credits course leading straight to Master's degree in 5 years. Students can choose a language of instruction through one of the Department they choose to study at: a German, an Italian and a Ladin. The Department in German offers German, Italian (at least 30 ECTS credits), English (at least 15 ECTS credits). The Department in Italian offers the following languages of instruction: Italian, German (at least 30 ECTS credits), English (at least 15 ECTS credits). The Department in Ladin language offers Italian, German, Ladin and English (at least 15 ECTS credits) as languages of instruction. The curriculum offered at Italian Department includes modules on teaching Italian as mother tongue (10 ECTS credits), teaching Italian as Foreign Language, teaching Ladin, comparative grammar of Ladin and German (10 ECTS credits), English and teaching English (10 ECTS credits), as well as developing multilingual literacy (8 ECTS credits). 10 ECTS credits are optional (among optional courses there are language-focused courses) and a language suitability course (2 ECTS credits). Moreover, to increase the level of students' preparedness to work in a multilingual environment, future teachers work in small groups and language labs. Practical training of future primary school FL teachers comprises 45 ECTS credits (15\% of curriculum) [13].

There are several peculiarities of Italian model of generalist teacher training. First, it is tailored to the needs of the region where graduates are going to work. Secondly, enrollees can choose the language of instruction 
according to their level of language proficiency. Thirdly, students learn practical language teaching skills from theory, and develop practical skills in language labs and during internship [13].

Semi-specialist teachers can teach at least 3 subjects at primary schools. The combination of these subjects depends on the needs of local educational authorities, schools, and individual choice of a university or higher educational institution [4, p. 85].

According to the Eurydice report, only Danish educational system requires FL teachers in primary schools to be qualified according to semispecialist model. The University College South Denmark offers students the choice of Danish, English, and Maths as their first subject. Bachelor's program comprises 240 ECTS credits and students can choose subjects they want to teach among the following: Visual arts, Biology, Danish, English, Science, Geography, History, Crafts and Design, Sports, Religion, Food Science, Maths, Music, Nature and Technology, Social studies and German. Students organize their learning path through enrolling into subjects aiming at developing teacher's basic skills (60-70 ECTS credits), teaching subjects (120-130 ECTS credits), undergoing internship (30 ECTS credits) and writing Bachelor's project ( 20 ECTS credits) [22, pp. 4-5].

Having analyzed Danish model of semi-specialist teacher training, we can assume primary school FL teacher training (Danish and English as FL in primary schools) can occupy up to 80 ECTS credits $(33.3 \%)$ of the curriculum.

Examples of countries, where there are no specific regulations on the qualification of primary school FL teacher are the UK, Finland, and Estonia. Let us have a look at the Finnish case of preparing primary school teachers to teaching FL at the University of Jyväskylä. Only those teachers who have Master's degree (300 ECTS credits) are admitted to work as classroom teachers (primary school teachers). Students can enroll into elective courses within the curriculum (up to 37 ECTS credits) and choose their minor qualification. As Finnish primary school teachers are not qualified to teach FL, unless they have chosen to obtain such speciality, Finnish example belongs to semi-specialist teacher training. Among the minors the Jyväskylä University offers a JULIET programme (Jyväskylä University Language Innovations and Educational Theory) with English as a language of instruction. This programme includes 7 courses (35 ECTS credits) offered 
during 5 years of studies. Throughout years 1-3, the program is focused on culture, creativity and language, academic language skills, varieties of English, the language of education and pedagogy and theories of foreign language pedagogy. Throughout years 4-5 the program aims at teaching ways to integrate content or subject studies with foreign language integrated learning. Whereas the basic courses focus on the teaching of English within the Finnish educational system the advanced courses (Language development and cultural understanding, The role of language in education and foreign language pedagogy, Content and language integrated learning, Studies in international and intercultural education) take a broader view of foreign language pedagogy looking at international and intercultural aspects of education and specializing in Content and Language Integrated Learning (CLIL) [15].

We have analysed the curriculum and the JULIET program comprises $11.6 \%$ of the curriculum of future primary school FL teacher training.

The third model of graduate is the Specialist teacher model. According to this model, teachers (philologists) can teach one or two language subjects at a primary school. Usually, these teachers have studied a FL and languagerelated subjects, as well as passed the course on teaching FL to young learners [4, p. 85].

According to Eurydice, only specialist teachers are allowed to teach FL in primary schools in: Greece, Spain, Croatia, Portugal, Slovakia, Bosnia and Herzegovina, Montenegro, the former Yugoslav Republic of Macedonia and Turkey [4, p. 86].

Let us have a look at a Portuguese example of specialist teacher training at the University of Lisbon. Students can enroll into the Bachelor's program "Languages, Literatures and Cultures" (180 ECTS credits) and study, for instance, 1 major (German, Spanish, French, English, Italian) with 60 ECTS credits and 2 minors (among language related minors, there are: German Studies, Asian Studies, Classical Studies, Slavic Studies, English Studies, North American Studies, Spanish Language and Linguistics, French Language and Linguistics, English Language and Linguistics, Portuguese Language, Translation) with at least 30 ECTS credits (Universidade de Lisboa, 2020). However, to be eligible to teach FL at schools, future teachers should graduate Master's degree. Examples of programs allowing teaching at primary schools are "Teaching English in the 1st Cycle of Basic 
Education" (90 ECTS credits) and "Portuguese as a Foreign Language/ Second Language" (120 ECTS credits). These courses comprise the methodology of teaching block. It provides graduates with necessary skills of teaching FL.

According to the specialist FL training model, future FL teachers study the language of their choice as major or minor at Bachelor's level. Then they apply to Master's degree program leading to FL teaching qualification.

\section{Primary school FL teacher training in Ukraine}

Having analysed European models of higher education for future primary school FL teachers, we make an attempt to categorize models of FL primary school teacher training in Ukraine.

The legislative provision of structural model functioning in Ukraine is: Law "On Education" (2017), Law "On Professional Pre-Higher Education" (2019), Law "On Higher Education" (2014). The Law "On Professional Pre-Higher Education" was recently introduced to be implemented in 2020. Based on these laws, future primary school FL teachers are prepared in colleges and universities. Thus, a binary model of teacher training is implemented in Ukraine.

There are no specific regulations towards the qualification of teachers, who are allowed to teach FL to primary school students. For instance, at Pedagogical Institute (Borys Grinchenko Kyiv University) students are offered a 240 ECTS credit Bachelor's programme (180 ECTS credits are compulsory and 60 ECTS credits are for specialization) [36]. Students study general pedagogical subjects, undergo primary school subjectspecific training, study a block of specialization subjects, internship and certification procedures. Pedagogical internship takes place from the first semester of studies to the last one and comprises $31.8 \%$ of the curriculum. Thus, we can conclude future primary school FL teachers are trained within a concurrent model as generalist teachers.

Programs, offering specialist teachers training are focused mainly on learning languages. For example, 240 ECTS credits Bachelor's curriculum "Language and Literature (English) offers students to study general pedagogical subjects, English as their major (123 ECTS credits), the second FL (60 ECTS credits), undergo internship and certification. To be able to teach these languages, future FL teachers study a compulsory course 
"Methodology of Teaching English" (11 ECTS credits) [37]. However, only a part of this course is devoted to teaching young learners, in contrary to "Primary School" students, who study teaching methodology.

There are only 2 graduate models, generally applied towards preparing future primary school FL teachers in Ukraine: generalist and specialist models. Structurally, Ukrainian system of higher education is binary with university and non-university sectors, where future teachers are qualified. Additionally, there is no state regulation on the functional model to be applied, so higher educational institutions provide the concurrent model.

\section{Conclusions}

Based on the literature review, we were able to present a comprehensive model of higher education for future FL teachers in primary schools. The analysis of European legislative provision, Eurydice reports, legislative provision for higher education of individual European countries and curriculums of teacher training allowed us to distinguish three types of structural models. They are representing the structure of higher education at ISCED 6 and 7 levels. We have analysed Belgian higher education in the paper. It is represented by a university and non-university sector, where academically and professionally oriented education is provided. Finnish case of unitary model of higher education is represented by universities and colleges, which belong to them. Differential model of French higher education comprises long and short cycles of education provided by different educational institutions.

The case of concurrent model of teacher training is analysed in Luxembourg and the Czech Republic. It was found out that teacher training takes place at either Bachelor's level or in the curriculum leading straight to Master's degree. The amount of credits assigned for pedagogical internship varies in these cases. The German and French cases of consecutive model of teacher training demonstrated there are different regulations regarding institutions, providing internship: either they are a part of the university or independent from it.

The results indicate that across Europe there are three models of FL teachers' qualification: generalist teachers, semi-specialist teachers and specialist teachers. The analysis of curriculums of primary school teacher training in multilingual Luxembourg and Italy demonstrates there is 
difference in the amount of time suggested for language learning, learning methodology and internship. However, in both cases students have a part of curriculum presented in FL as a medium of instruction. Semi specialist teachers are prepared in Denmark and the curriculum analysis demonstrated the peculiarities of organizing theory and practice within major and minor subjects, which students are obliged to choose. However, Finnish case of primary school teacher training shows independent approach to FL qualification: students may or may not choose it. Specialist teacher training is represented by a Portuguese case. Future FL teachers first qualify as philologists and get their teaching profession afterwards.

Ukraine undergoes a process of reforms to be integrated into European Higher Educational Area. We have analysed the legislative provision of higher education and can conclude it is built according to a binary system. However, some of the laws are gradually coming into force. On the example of Borys Grinchenko Kyiv University we found out generalist teacher training is functioning similarly to the European. However, the amount of practical training in the concurrent teacher training is significantly higher than across Europe. Preparation of semi-specialists is not provided in Ukraine. In the curriculum of specialist teacher training only a part of the course (less than $4.5 \%$ ) is devoted to teaching English as a second language to young learners.

Summing up the results, we can conclude Ukrainian system of FL teacher training corresponds to models functioning across Europe. However, a further research on tendencies of FL teacher training to teaching in primary schools is needed.

\section{References:}

1. Arrêté ministériel du 21 mai 2019 portant approbation du règlement des études de l'Université du Luxembourg. Retrieved from Journal officiel du GrandDuché de Luxembourg.

2. Bachelor en Sciences de l'Éducation. Année académique 2019-2020. Retrieved from University of Luxembourg: https://wwwen.uni.lu/studies/flshase/ bachelor_en_sciences_de_1_education/programme/cours_syllabus

3. Bachelor of Science in Education. Methodology. Retrieved from University of Luxembourg: https://wwwen.uni.lu/studies/flshase/bachelor_en_sciences_de_1_ education/programme/methodologie\#

4. Commission European/EACEA/Eurydice (2017). Key Data on Teaching Languages at School in Europe (2017 Edition ed.). Eurydice Report. Luxembourg: Publications Office of the European Union. doi: 10.2797/839825 
5. Cornu, B. (2015). Teacher Education in France: Universitisation and professionalisation - from IUFMs to ESPEs. Education Inquiry (6:3).

6. Décret définissant le paysage de l'enseignement supérieur et l'organisation académique des etudes (2013). Retrieved from Communauté française de Belgique: https://www.gallilex.cfwb.be/document/pdf/39681_008.pdf

7. Dekret Zur Schaffung Einer Autonomen Hochschule. Retrieved from Autonomen Hochschule in der Deutschsprachigen Gemeinschaft: http://www.pdg.be/ PortalData/4/Resources/downloads/koordek/2005-06-27-01.pdf

8. European Comission. Teachers and Education Staff. Retrieved from Eurydice: https://eacea.ec.europa.eu/national-policies/eurydice/general/9-teachers-and-education-staff_en

9. European Commission (2017). Preparing Teachers for Diversity: the Role of Initial Teacher Education. doi: 10.2766/637002

10. Eurydice. Finland Overview. Retrieved from Eurydice: https://eacea.ec.europa.eu/national-policies/eurydice/content/finland_en

11. Eurydice. Initial Education for Teachers Working in Early Childhood and School Education in France. Retrieved from Eurydice: https://eacea.ec.europa.eu/ national-policies/eurydice/france/initial-education-teachers-working-early-childhood-and-school-education_en

12. Eurydice. (n.d.). Initial Education for Teachers Working in Early Childhood and School Education. Retrieved from Eurydice: https://eacea.ec.europa.eu/ national-policies/eurydice/content/initial-education-teachers-working-early-childhood-and-school-education-20 en

13. Free University of Bolzano. Single cycle master's degree in Primary Education Sciences. Retrieved from Free University of Bolzano: https://www.unibz.it/ it/faculties/education/master-primary-education/

14. Hourigan, M., \& Leavy, A. (2018). The influence of entry route to teaching on Irish pre-service primary teachers' attitudes towards mathematics. Journal of Further and Higher Education, pp. 1-16.

15. JULIET program (2020). Retrieved from Jyväskylä University: https://www.jyu.fi/edupsy/fi/laitokset/okl/opiskelu/sivuaineet/juliet/en/study

16. Kavak, Y., \& Baskan, G. (2009). Restructuring studies of teacher education in recent years in Turkey. Procedia-Social and Behavioral Sciences, no. 1(1), pp. 364-367.

17. Kultusministerkonferenz (2019). Rahmenvereinbarung über die Ausbildung und Prüfung für ein Lehramt der Grundschule bzw. Primarstufe (Lehramtstyp 1). Retrieved from Kultusministerkonferenz: http://www.kmk.org/fileadmin/Dateien/ veroeffentlichungen_beschluesse/1997/1997_02_28-RV_Lehramtstyp_1.pdf

18. Land Brandenburg (2018). Gesetz über die Ausbildung und Prüfung für Lehrämter und die Fort- und Weiterbildung von Lehrerinnen und Lehrern im Land Brandenburg. Retrieved from Land Brandenburg: https://bravors.brandenburg.de/gesetze/bbglebig

19. Legifrance (2020). Code de l'éducation. Retrieved from France: https://www.legifrance.gouv.fr/affichCode.do?cidTexte=LEGITEXT000006071191

20. Loi du 24 février 1984 sur le régime des langues (1984). Retrieved 02 20, 2019, from Journal officiel du Grand-Duché de Luxembourg: http://data.legilux. public.lu/eli/etat/leg/loi/1984/02/24/n1/jo 
21. Loi du 27 juin 2018 ayant pour objet l'organisation de l'Université du Luxembourg (2018). Retrieved from: http://legilux.public.lu/eli/etat/leg/loi/2018/06/27/a587/jo

22. Læreruddannelsen ved UC SYD (2019). Retrieved from University College South Denmark: https://www.ucsyd.dk/files/inline-files/Studieordning\%20 2019\%20del\%201\%20-\%20lokale\%20bestemmelser.pdf

23. Martens, A. What is Educational Models. Retrieved from IGI Global Disseminator of Knowledge: https://www.igi-global.com/dictionary/models-learning-systems/36406

24. Masarykovy univerzity (2020). Učitelství pro 1. stupeň základni školy. Retrieved from Informační systém Masarykovy univerzity: https://is.muni.cz/predmety/studijni plan?plan id $=25777$

25. Oxford Learner's Dictionary. Model. Retrieved from https://www.oxfordlearnersdictionaries.com/definition/english/model_1?q=model

26. Raud, N., \& Orehhova, O. (2020). Training teachers for multilingual primary schools in Europe: key components of teacher education curricula. International Journal of Multilingualism, pp. 1-14.

27. Sederevičiūtè-Pačiauskienè, Ż., \& Vainorytè, B. (2015). The concurrent and consecutive models of initial teacher training : problematics and tendencies. Rural Environment. Education. Personality, 347-354. Retrieved from ResearchGate: https://www.researchgate.net/publication/281436373_The_concurrent_and_consecutive_models_of_initial_teacher_training_problematics_and_tendencies Rural_Enviroment_Education_Personality_REEP_Jelgava_Latvian_University_ of_Agriculture_2015_ISSN_2255-8071

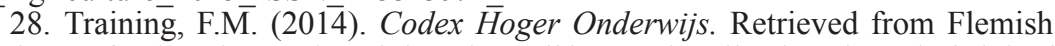
Ministry of Education and Training: https://data-onderwijs.vlaanderen.be/edulex/ document.aspx?docid $=14650$

29. UNESCO (2011). ISCED 2011. Retrieved from ISCED: http:/uis.unesco.org/ en/topic/international-standard-classification-education-isced

30. Universidade de Lisboa (2020). Línguas, Literaturas e Culturas. Получено из Universidade de Lisboa: https://www.letras.ulisboa.pt/pt/cursos/licenciaturas-1-ciclo/linguas-literaturas-e-culturas\#minor-em-tradu\% $\% 3 \% \mathrm{~A} 7 \% \mathrm{C} 3 \% \mathrm{~A} 3 \mathrm{o}$

31. Universities Act. Retrieved from Finlex Data Bank: https://www.finlex.fi/fi/ laki/kaannokset/2009/en20090558.pdf

32. University of Luxembourg. University of Luxembourg Language Centre (ULLC). Retrieved from University of Luxembourg: https://wwwen.uni.lu/university_of_luxembourg_language_centre_ullc

33. Zuzovsky, R., \& Donitsa-Schmidt, S. (2017). Comparing the effectiveness of two models of initial teacher education programmes in Israel: concurrent vs. consecutive. European Journal of Teacher Education. doi: 10.1080/02619768.2017.1318377

34. Vitvytska, S. (2015). Komparatyvnyi analiz modelei stupenevoi pedahohichnoi osvity Velykobrytanii ta Ukrainy. Problemy osvity: zbirnyk naukovykh prats. Spetsvypusk, pp. 17-22.

35. Natsionalna stratehiia rozvytku osvity v Ukraini na period do 2021 roku (2013). Retrieved from: Verkhovna Rada: http://zakon5.rada.gov.ua/laws/ show/344/2013\#n10 
36. Kyivskyi universytet imeni Borysa Hrinchenka (2018). Osvitno-profesiina prohrama 013.00.01 «Pochatkova osvita». Retrieved from: http://kubg.edu.ua/ images/stories/Departaments/vstupnikam/pi/po_bak_opys-2018.pdf

37. Kyivskyi universytet imeni Borysa Hrinchenka (2018). Filolohiia. Mova $i$ literatura (anhliiska). Retrieved from: http://kubg.edu.ua/informatsiya/vstupnikam/napryami-pidgotovki/bakalavr.html\#035-філологія-освітня-програмамова-і-література-англійська

38. Ministerstvo osvity i nauky (2018). Kontseptsiia rozvytku pedahohichnoi osvity. Retrieved from: https://mon.gov.ua/ua/npa/pro-zatverdzhennya-koncepciyi-rozvitku-pedagogichnoyi-osviti 